\title{
LAMA PERSALINAN KALA III DAN PROSES INVOLUSI UTERI MEMPENGARUHI INISIASI MENYUSU DINI PADA IBU POST PARTUM
}

\author{
Justina Purwarini $^{12^{*}}$, Yeni Rustina ${ }^{3}$, Yusron Nasution ${ }^{4}$ \\ 1. Sekolah Tinggi Ilmu Kesehatan Sint Carolus Jakarta, Jakarta 10440, Indonesia \\ 2. Program Studi Magister Fakultas Ilmu Keperawatan Universitas Indonesia, Depok 16424, Indonesia \\ 3. Fakultas Ilmu Keperawatan Universitas Indonesia, Depok 16424, Indonesia \\ 4. Fakultas Kesehatan Masyarakat Universitas Indonesia, Depok 16424, Indonesia \\ *Email:atiek96@yahoo.com
}

\begin{abstract}
Abstrak
Inisiasi menyusu dini atau permulaan menyusu dini merupakan perilaku bayi mulai menyusu sendiri segera setelah lahir. Saat bayi mulai melakukan hentakan kepala ke dada ibu, sentuhan tangan dan hisapan bayi di puting susu ibu merangsang pengeluaran hormon oksitosin. Oksitosin diperlukan ibu saat persalinan untuk mencegah terjadinya perdarahan dengan mempengaruhi rahim berkontraksi sehingga membantu pengeluaran plasenta dan juga membantu proses involusi uteri. Penelitian ini bertujuan untuk mengidentifikasi pengaruh inisiasi menyusu dini terhadap lamanya persalinan kala III dan proses involusi uteri pada ibu post partum. Penelitian ini menggunakan sampel 60 responden, masing-masing kelompok kontrol dan kelompok intervensi 30 responden. Data dianalisa secara univariat dan bivariat menggunakan Chi-Square dan $t$ test independent. Hasil penelitian menunjukkan bahwa ada perbedaan yang signifikan lamanya persalinan kala III pada kelompok kontrol dan kelompok intervensi $(\mathrm{p}=0,000 ; \alpha=0,05)$. Penelitian ini juga memperlihatkan adanya perbedaan yang siginfikan proses involusi uteri pada kelompok kontrol dan kelompok intervensi $(p=0,000 ; \alpha=0,05)$. Diharapkan penelitian ini dapat memberi manfaat bagi peningkatan pelayanan dan pendidikan serta perkembangan ilmu keperawatan dan bagi pengambil kebijakan untuk menggunakan inisiasi menyusu dini dalam praktek keperawatan profesional.
\end{abstract}

Kata kunci: Inisiasi menyusu dini, oksitosin, lama persalinan kala III, involusi uteri

\begin{abstract}
Early breastfeeding inisiation or the beginning of early breastfeeding is baby's behaviour where the baby starts to feed by themselves as soon as they were born. When baby starts to make contact to mother's breast, the touch of their hands and their sucking reflex at mother's nipple stimulate the releasing of oxytocin hormones. Oxytocin is needed when woman is in labour process to prevent bleeding by making utery to contract more and it will help the birth of placenta and also helping utery involution process. The aim of this research was to identify the effect of early breastfeeding inisiation to duration of the thirdstage of labor and involution of the uterus process for mother in post partum period. This research design was used for this study with total samples were 60 patients, divided into control group and intervention group, with each of the group had 30 patients. Data were analyzed with univariat and bivariat using Chi-Square and t test independent. The result of this research showed that there were a significant difference on duration of the third-stage of labour between control group and intervention group $(p=0.000 ; \alpha=0.05)$. This research also showed a significant difference on involution of the uterus process between control group and intervention group $(p=0.000 ; \alpha=0.05)$. This research hopefully will gives benefit for improvement of nursing care at health institution and nursing education and also for the development of nursing science and for decision maker to implement early breastfeeding in professional nursing practice.
\end{abstract}

Keywords: early breastfeeding inisiation, oxytocin, duration of the third-stage of labour, involution of the uterus

\section{Pendahuluan}

Perdarahan menjadi salah satu penyebab besarnya angka kematian ibu bertanggung jawab atas $28 \%$ kematian ibu. Sebagian besar kasus perdarahan dalam masa nifas terjadi karena retensio plasenta dan atonia uteri(UNDP, 2004). Ripley (1999) juga mengatakan bahwa sebab paling umum dari perdarahan pasca persalinan yang terjadi dalam 24 jam sete- lah melahirkan ialah atonia uteri (kegagalan rahim berkontraksi setelah melahirkan). Manajemen persalinan kala III penting mencegah komplikasi.

Manajemen aktif persalinan kala III merupakan intervensi yang direncanakan untuk mempercepat pelepasan plasenta dalam mencegah perdarahan post partum dengan meningkatkan kontraksi rahim sehingga menghindari terjadinya atonia uteri. 
Komponennya adalah: (1) Memberikan obat uterotonika (untuk kontraksi rahim) dalam waktu dua menit setelah kelahiran bayi; (2) menjepit dan memotong tali pusat segera setelah melahirkan; (3) melakukan peregangan tali pusat terkendali sambil secara bersamaan melakukan tekanan terhadap rahim melalui perut. Setelah pelepasan plasenta, memijat uterus juga dapat membantu kontraksi mengurangi perdarahan (Shane, 2002).

Saat setelah kelahiran bayi dan jam-jam pertama pasca persalinan merupakan saat-saat penting untuk pencegahan, diagnosa, dan penanganan risiko perdarahan. Dibandingkan dengan risikorisiko lain pada ibu seperti infeksi, maka kasus perdarahan dengan cepat dapat mengancam jiwa. Seorang ibu dengan perdarahan hebat akan cepat meniggal apabila tidak mendapatkan penanganan segera.

Pada kehamilan cukup bulan aliran darah ke uterus sebanyak 500-800 ml/menit. Jika uterus tidak berkontraksi dengan segera setelah kelahiran plasenta, maka ibu dapat mengalami perdarahan sekitar 350-500 ml/menit dari bekas tempat melekatnya plasenta. Kontraksi uterus akan menekan pembuluh darah uterus yang berjalan diantara anyaman serabut miometrium sehingga menghentikan darah yang mengalir melalui ujung-ujung arteri di tempat implantasi plasenta (Bobak \& Jensen, 2006).

Berdasarkan laporan audit kematian maternal Dinkes Bali (2004), terdapat 55 kasus AKI. Berdasarkan jumlah tersebut, 34,5\% akibat perdarahan saat melahirkan. Salah satu penyebab perdarahan setelah melahirkan adalah lemahnya kontraksi rahim/uterus. Cara mengurangi terjadinya perdarahan saat melahirkan antara lain dengan sesegera mungkin menyusui bayi dalam kurun waktu 30 menit sampai satu jam setelah lahir.

Oleh karena itu, untuk meminimalkan terjadinya perdarahan saat melahirkan, proses melahirkan harus dibantu oleh tenaga kesehatan yang berkompeten. Tenaga kesehatan merupakan faktor- faktor yang sangat berpengaruh terhadap pelaksanaan manajemen aktif kala III dalam pertolongan persalinan (Sumantri \& Siswishanto, 2007).

Salah satu uterotonika yang sering diberikan pada ibu saat memasuki kala III adalah suntikan oksitosin. Hormon oksitosin diharapkan dapat merangsang uterus berkontraksi yang juga mempercepat pelepasan plasenta. Jika oksitosin tidak tersedia, merangsang puting payudara ibu dapat dilakukan atau menyusukan bayi guna menghasilkan oksitosin alamiah.

Kontraksi uterus sangat diperlukan untuk proses involusi yaitu proses kembalinya uterus kepada keadaan sebelum hamil setelah melahirkan. Proses ini dimulai segera setelah plasenta keluar akibat kontraksi otot-otot polos uterus. Biasanya uterus tidak bisa dipalpasi pada abdomen pada hari ke-9 post partum (Bobak, Lowdermilk, \& Jensen, 2005).

Salah satu upaya untuk merangsang kontraksi uterus adalah dengan pemberian ASI secara dini. Pada proses menyusui, oksitosin memiliki peranan yang besar dalam menghasilkan produksi ASI. Aktifitas oksitosin tidak hanya menyebabkan kontaksi otot-otot myoepitelial disekitar alveoli mammae, tetapi juga memberikan efek pada reflek neuroendokrin, memproduksi analgetik, mengurangi respon stres dan kecemasan, menyebabkan kontraksi uterus dan berperan meningkatkan perilaku bonding pada ibu dan bayi (Gimpl \& Fahrenholz, 2001).

Insting dan refleks bayi yang sangat kuat dalam satu jam pertama menghisap diharapkan akan memberi stimulus bagi kelancaran pemberian ASI selanjutnya sehingga ASI eksklusif dapat diberikan. Keuntungan yang didapatkan ibu dari pelaksanaan inisiasi menyusu dini adalah saat hentakan kepala bayi ke dada ibu, sentuhan tangan bayi di puting susu dan sekitarnya, hisapan dan jilatan pada puting ibu merangsang pengeluaran hormon oksitosin (Roesli, 2008). 
Tujuan penelitian adalah melihat pengaruh inisiasi menyusu dini terhadap lamanya persalinan kala III dan proses involusi uterus pada ibu post partum.

\section{Metode}

Jenis penelitian ini adalah penelitian kuantitatif dengan menggunakan desain kuasi eksperimen. Dalam penelitian ini peneliti memberikan perlakuan atau intervensi pada subyek penelitian, kemudian efek perlakuan diukur dan dianalisis. Pemilihan kelompok kontrol dan kelompok intervensi tidak menggunakan tehnik random karena perlakuan yang diberikan berhubungan dengan kebijakan institusi kesehatan di tempat penelitian dilakukan.

Dalam penelitian ini pengukuran dilakukan setelah kelompok intervensi dilakukan inisiasi menyusu dini, sedangkan pada kelompok kontrol tidak diberikan perlakuan inisiasi menyusu dini. Pengukuran dilakukan pada kedua kelompok pada saat proses persalinan khususnya kala III dan setelah persalinan sampai dengan 9 hari post partum.
Sampel dalam penelitian ini sebanyak 60 responden yang terbagi menjadi 30 orang kelompok intervensi dan 30 orang kelompok kontrol. RSUD A dipilih sebagai tempat penelitian dengan kelompok intervensi, sedangkan RSUD B dipilih sebagai tempat penelitian dengan kelompok kontrol. Penelitian dilaksanakan awal Mei sampai dengan pertengahan Juni 2008.

Pengumpulan data dilakukan dengan cara peneliti sebelumnya telah membagi kelompok berkaitan menjadi kelompok intervensi dan kelompok kontrol. Selanjutnya peneliti melakukan intervensi pada kelompok yang telah ditentukan. Sedangkan pada kelompok kontrol peneliti tidak melakukan intervensi.

Lama persalinan kala III dan proses involusi uteri mulai diukur pada saat proses persalinan sampai dengan 9 hari post partum pada kedua kelompok tersebut. Pengambilan data dilakukan dengan cara observasi dan memberikan kuesioner pada responden. Data dianalisa secara univariat dan bivariat. Pada analisa bivariat digunakan t-test independent dan Chi-Square.

Tabel 1. Distribusi Rata-Rata Lama Persalinan Kala III Menurut Perlakuan Inisiasi Menyusu Dini

\begin{tabular}{lcccc}
\hline & Kelompok & \multicolumn{4}{c}{ Lama persalinan kala III } \\
\cline { 2 - 5 } & $\mathbf{n}$ & Mean & SD & p \\
\hline Kontrol & 30 & 10,80 & 4,19 & 0,000 \\
\multirow{2}{*}{ Intervensi } & 30 & 5,57 & 1,55 & \\
\hline
\end{tabular}

\section{Hasil}

\section{Distribusi Lama Persalinan Kala III dengan Inisiasi Menyusu Dini}

Tabel 1 memperlihatkan bahwa rata-rata lamanya persalinan kala III pada kelompok yang tidak dilakukan IMD adalah 10,80 menit dengan standart deviasi 4,189. Sedangkan untuk lamanya persalinan kala III pada kelompok yang dilakukan IMD adalah 5,57 menit dengan standar deviasi 1,547. Hal ini berarti selisih rata-rata lamanya persalinan kala III pada kelompok yang melakukan dan tidak melakukan IMD adalah 5,23 menit.

Penelitian ini juga memperlihatkan bahwa ada perbedaan yang bermakna lamanya persalinan kala III dengan pemberian perlakuan inisiasi menyusu dini pada kelompok kontrol dan kelompok intervensi $(p=0,000 ; \alpha=0,05)$. 


\section{Distribusi Responden Menurut Perlakuan Inisiasi Menyusu Dini dan Proses Involusi Uteri}

Hasil menunjukkan bahwa proporsi responden pada kelompok kontrol dan mengalami proses involusi uteri yang tidak normal 96,7\% (29 responden), sisanya 3,3\% (1 responden) mengalami proses involusi yang normal. Sedangkan proporsi responden pada kelompok intervensi dan mengalami proses involusi normal adalah 73,3\% (22 orang) dan sisanya sebanyak $26,7 \%$ ( 8 responden) mengalami proses involusi yang tidak normal. Berdasarkan hasil perhitungan juga diketahui ada perbedan proporsi yang bermakna antara perlakuan IMD dengan proses involusi uteri $(p=0,000$; $\alpha=0,05$ ) (lihat pada tabel 2).

\section{Waktu Keberhasilan Inisiasi Menyusu Dini}

Hasil analisis didapatkan bahwa pada kelompok intervensi rata-rata waktu yang diperlukan bayi untuk berhasil melakukan inisiasi menyusu dini adalah 63,3 menit dengan standar deviasi 13,75. Berdasarkan hasil estimasi interval dapat disimpulkan bahwa pada kelompok intervensi 95\% diyakini rata-rata waktu yang diperlukan bayi untuk berhasil melakukan inisiasi menyusu dini adalah antara 59,70 sampai dengan 68,17 menit (lihat pada tabel 3).

\section{Pembahasan}

Rata-rata lama persalinan kala III pada kelompok kontrol adalah 10,8 menit sedangkan pada kelompok intervensi, rata-rata lama persalinan kala III adalah 5,57 menit. Sesuai dengan studi literatur yang diperoleh bahwa pada kondisi normal, kala III biasanya berlangsung 3 sampai 4 menit untuk primipara dan 4 sampai 5 menit untuk multipara. Waktu maksimal yang diperlukan untuk melahirkan plasenta adalah 45 sampai 60 menit (Bobak \& Jensen, 2006).

Plasenta akan sulit lepas pada uterus yang kendur karena ukuran permukaan sisi plasenta tidak akan berkurang. Waktu yang diperlukan untuk kala III tergantung dari kontraksi uterus yang terjadi. Kontraksi ini akan menekan pembuluh darah sehingga menghentikan darah yang mengalir melalui ujung-ujung arteri di tempat implantasi plasenta. Dengan waktu seminimal mungkin untuk plasenta lahir, diharapkan risiko perdarahan pada ibu akan semakin berkurang. Hal ini sejalan dengan penelitian yang dilakukan juga oleh Bilgic, Guler, dan Cetin (2004), yang menemukan bahwa inisiasi menyusu dini akan meningkatkan kelahiran plasenta menjadi lebih awal.

Tabel 2. Distribusi Responden Menurut Perlakuan Inisiasi Menyusu Dini dan Proses Involusi Uteri

\begin{tabular}{|c|c|c|c|c|c|}
\hline \multirow{3}{*}{ Involusi Uteri } & \multicolumn{4}{|c|}{ Kel ompok } & \multirow{3}{*}{$\mathbf{p}$} \\
\hline & \multicolumn{2}{|c|}{ Kontrol } & \multicolumn{2}{|c|}{ Intervensi } & \\
\hline & $\mathbf{f}$ & $\%$ & $\mathbf{f}$ & $\%$ & \\
\hline Tidak nor mal & 29 & 96,7 & 8 & 26,7 & 0,000 \\
\hline Normal & 1 & 3,3 & 22 & 73,3 & \\
\hline
\end{tabular}

Hasil uji t-test independent didapatkan bahwa ada perbedaan yang bermakna antara lama waktu lamanya persalinan kala III dengan perlakuan inisiasi menyusu dini pada kelompok kontrol dan kelompok intervensi $(p=0,000 ; \alpha=0,05)$. Persalinan kala III terjadi karena adanya kontraksi uterus yang di stimulus oleh hormon oksitosin. Pada proses inisiasi menyusu dini, saat bayi mulai merangkak di dada ibu, sentuhan tangan di puting susu, dan hentakan kepala bayi pada dada ibu akan merangsang pengeluaran oksitosin (Roesli, 2008).

Pada kelompok kontrol proses involusi uteri normal hanya 3,3\% (1 responden) sedangkan pada kelompok intervensi didapat 73,3\% (22 responden). 
Untuk analisa bivariat didapatkan hasil adanya hubungan yang bermakna antara perlakuan inisiasi menyusu dini dengan proses involusi uteri $(\mathrm{p}=0,000 ; \alpha=0,05)$. Hasil penelitian ini didukung dengan uji statistik yang memperlihatkan bahwa responden yang mendapatkan perlakuan memiliki kemungkinan 80 kali lebih besar untuk mengalami proses involusi yang normal dibandingkan dengan responden pada kelompok kontrol.

Hasil penelitian ini didukung oleh Siswono (2001) yang mengatakan bahwa isapan bayi pada payudara merangsang terbentuknya oksitosin oleh kelenjar hipofisis. Oksitosin akan membantu involusi uteri dan mencegah terjadinya perdarahan.

Inisiasi menyusu dini diharapkan akan menjadi awal dari berlangsungnya pemberian ASI eksklusif. Seperti yang dikatakan oleh Fikawati dan Syafiq (2003) bahwa bayi yang diberikan kesempatan untuk menyusu dini, hasilnya delapan kali lebih berhasil untuk ASI eksklusif. Pemberian ASI eksklusif juga akan membantu proses involusi uteri ibu post partum.

Hal tersebut bisa disebabkan karena ibu terus memberikan ASI, sehingga produksi oksitosin akan terus dihasilkan dan ini akan berpengaruh terhadap kontraksi uterus yang akan mempengaruhi proses involusi uteri. Sejalan dengan itu, Labbok (1999) juga berpendapat bahwa menyusui meningkatkan pengeluaran oksitosin yang menghasilkan proses involusi uteri yang cepat dan berkurangnya perdarahan post partum serta insiden anemia post partum.

Pada penelitian ini didapatkan juga bahwa pada kelompok intervensi rata-rata lama waktu yang dibutuhkan bayi untuk dapat mencapai puting susu ibu adalah 63,3 menit. Hasil ini sesuai dengan pernyataan oleh Roesli (2008) bahwa waktu yang dibutuhkan bayi untuk melakukan inisiasi menyusu dini \pm 1 jam.

Tabel 3. Distribusi Waktu Keberhasilan Inisiasi Menyusu Dini pada Kelompok Intervensi

\begin{tabular}{rccc}
\hline Variabel & Mean & SD & 95\% CI \\
\hline Inisiasi Menyusu Dini & 63,3 & 13,75 & $57,9-68,2$ \\
\hline
\end{tabular}

\section{Kesimpulan}

Hasil penelitian menunjukkan bahwa waktu lamanya persalinan kala III dan proses involusi uteri mempengaruhi inisiasi menyusu dini pada ibu post partum. Hasil penelitian ini juga menunjukkan bahwa waktu rata-rata yang diperlukan bayi untuk melakukan inisiasi menyusu dini, yaitu bayi mencapai puting susu ibu adalah 63,3 menit.

Inisiasi menyusu dini menjadi salah satu cara untuk mengurangi angka kematian ibu dan bayi. Pasien berhak untuk menerima asuhan yang tepat dan berguna dari tenaga kesehatan. Pendidikan dan latihan tentang inisiasi menyusu dini bagi tenaga perawat perlu lebih disosialisasikan untuk meningkatkan kompetensi profesional yang mereka miliki dalam meningkatkan kualitas pelayanan.

Manajer keperawatan di tatanan pelayanan kesehatan diharapkan dapat mengembangkan dan membuat standar asuhan untuk inisiasi menyusu dini (IMD) serta menerapkannya dalam upaya meningkatkan kualitas hidup ibu dan bayi. Rekomendasi untuk penelitian lanjut mengenai inisiasi menyusu dini (IMD) dengan memperhatikan faktor-faktor confounding serta pengambilan sampel yang lebih banyak dan variatif sehingga hasil yang didapatkan menjadi lebih representatif (AT, SW, TN). 


\section{Referensi}

Bilgic, D., Guler, H., \& Cetin, A. (2004). Does early breastfeeding decrease the duration thirdstage of labor and enhance the infant-mother interaction. J Turkish German Gynecol Assoc, 5 (3), 208-212.

Bobak, M.I., \& Jensen, D.M. (2006). Essential of maternity nursing (6th Ed.). Toronto, USA: The C.V. Mosby Company.

Fikawati, S., \& Syafiq, A. (2003). Hubungan antara menyusui segera dan pemberian ASI eksklusif sampai usia 4 bulan. Jurnal Kedokteran Trisakti, 22 (2). Jakarta: Fakultas Kedokteran Universitas Trisakti.

Gimpl, G., \& Fahrenholz, F. (2001). The oxytocin receptor system: Structure, function, and regulation. The Physiological Rev, 81, 629-683.

Labbok, M.H. (1999). Health sequelae of breastfeeding for the mother. Clin perinatol. 26, 491-503.

Ripley, D.L. (1999). Uterine emergencies: Atony, inversion, and rupture. Obstetrics and Gynecology Clinics of North America, 26, 419-434.
Roesli, U. (2008). Inisiasi menyusu dini. Jakarta: Pustaka Bunda.

Shane, B. (2002). Mencegah persalinan pasca persalinan: Menangani persalinan kala tiga. Diperoleh dari http://www.path.org/files/ Indonesian_19-3.pdf.

Siswono. (2001). Penelitian perkembangan model pelayanan kesehatan reproduksi remaja. Jakarta: Badan Litbang Kesehatan Departemen Kesehatan dan Kesejahteraan Sosial.

Sumantri, D.D., \& Siswishanto, R. (2007). Faktor-faktor yang berpengaruh terhadap pelaksanaan manajemen aktif kala III oleh bidan dalam pertolongan persalinan di kabupaten klaten. Diperoleh dari http:// www.mkia-kr.ugm.ac.id.

United Nations Development Programme (UNDP). (2004). Laporan perkembangan pencapaian tujuan pembangunan milenium Indonesia. Diperoleh dari www.undp.or.id/pubs/imdg 2004/BI/IndonesiaMDG_BI_Goal5.pdf.

WHO. (1989). Ten steps to succesfull breastfeeding. Diperoleh dari http://BFHI_Revised_section 2.4.a transparancies. 